\title{
Transbilayer Complementarity of Phospholipids. A Look Beyond the Fluid Mosaic Model
}

\author{
Jianbing Zhang, Bingwen Jing, Nobuya Tokutake, and Steven L. Regen
}

Department of Chemistry, Lehigh University, Bethlehem, Pennsylvania 18015

Supporting Information
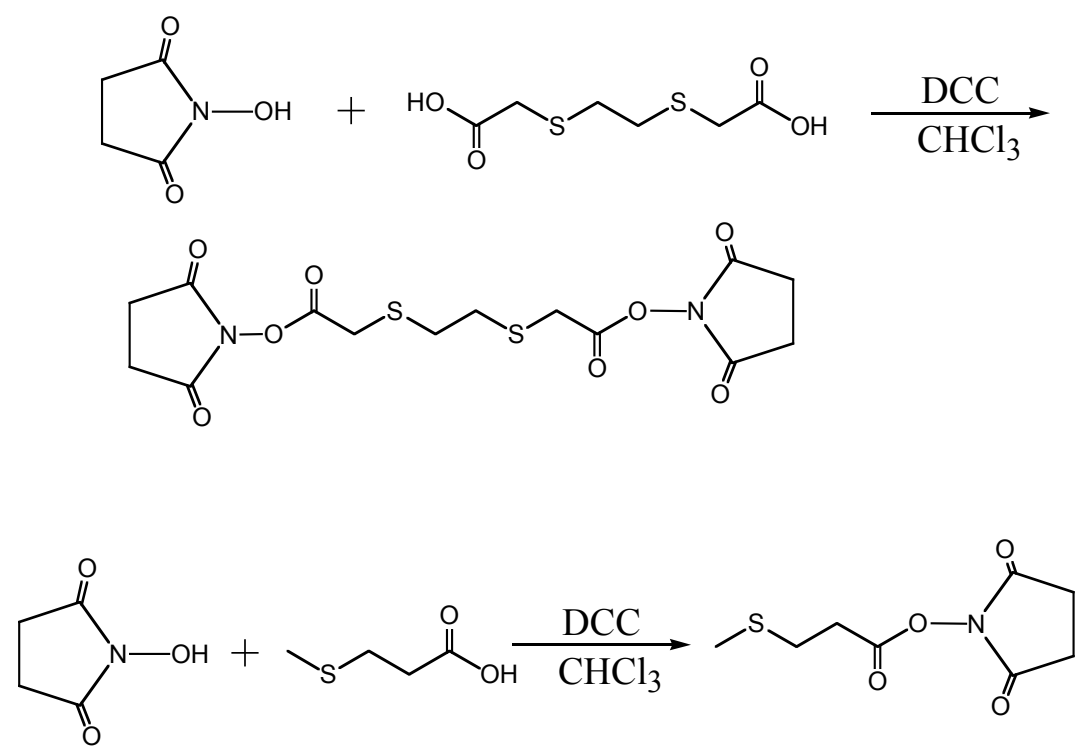

Synthesis of Compound I. $2.5 \mathrm{mmol}$ (525 mg, Fluka) of 2,2'-(ethylenedithio)diacetic acid and $5.0 \mathrm{mmol}(575 \mathrm{mg}$, Aldrich) of N-hydroxysuccinimide were dissolved in $10 \mathrm{~mL}$ of chloroform and the resulting solution stirred for $5 \mathrm{~min}$. $5.5 \mathrm{mmol}(1.13 \mathrm{~g}$, Aldrich) of N.N'-dicyclohexylcarbodiimide (DCC) was then added and the mixture stirred overnight. After filtration and solvent removal under reduced pressure, the residue was recrystallized with methanol three times to give $500 \mathrm{mg}(50 \%)$ compound I having ${ }^{1} \mathrm{HNMR}\left(\mathrm{CDCl}_{3}, 360 \mathrm{MHz}\right): 2.83(\mathrm{~s}, 8 \mathrm{H}), 3.05(\mathrm{~s}, 4 \mathrm{H}), 3.52(\mathrm{~s}, 4 \mathrm{H})$.

Synthesis of Compound II. $5.0 \mathrm{mmol}$ (600 mg, Lancaster) of 3-(methylthio)propionic acid and $5.0 \mathrm{mmol}(575 \mathrm{mg}$, Aldrich) of N-hydroxysuccinimide were dissolved in $10 \mathrm{~mL}$ of chloroform and the resulting solution then stirred for $5 \mathrm{~min} .5 .5 \mathrm{mmol}(1.13 \mathrm{~g}$, Aldrich) of N.N'-dicyclohexylcarbodiimide (DCC) was then added and the mixture stirred overnight. After filtration and solvent removal under reduced pressure, the residue was recrystallized with methanol three times to give $600 \mathrm{mg}(55 \%)$ of compound II having ${ }^{1} \mathrm{HNMR}\left(\mathrm{CDCl}_{3}, 360 \mathrm{MHz}\right): 2.99(\mathrm{~s}, 3 \mathrm{H}), 2.82-2.85(\mathrm{~m}, \mathrm{br}, 6 \mathrm{H}), 2.89-2.94(\mathrm{~m}$, br, $2 \mathrm{H})$. 
Synthesis of A'A'. $0.1 \mathrm{mmol}$ (63.6 mg) 1,2-dimyristoyl-sn-glycero-3phosphoethanolamine and $0.3 \mathrm{mmol}$ of triethlyamine (TEA) were dissolved in $2 \mathrm{~mL}$ of chloroform. After stirring for $5 \mathrm{~min}$ at RT, $0.05 \mathrm{mmol}(20.2 \mathrm{mg})$ of the activated ester (compound I) was added as powder. The resulting reaction mixture was stirred overnight. The solvent was then removed under reduced pressure and the residue was dissolved in chloroform and washed with $0.03 \mathrm{M} \mathrm{HCl}$ solution. The organic layer was then dried by $\mathrm{MgSO}_{4}$. Removal of solvent under reduced pressure, followed by chromatographic purification via preparative thin layer chromatography [silica, $\left.\mathrm{CHCl}_{3} / \mathrm{CH}_{3} \mathrm{OH} / \mathrm{H}_{2} \mathrm{O}, 65 / 25 / 4(\mathrm{v} / \mathrm{v} / \mathrm{v})\right]$ afforded $38 \mathrm{mg}(50 \%)$ of $\mathbf{A}^{\prime} \mathbf{A}^{\prime}$ having $\mathrm{R}_{\mathrm{f}} 0.41$ and ${ }^{1} \mathrm{HNMR}\left(\mathrm{CDCl}_{3}, 500 \mathrm{MHz}\right): 0.86(\mathrm{t}, 12 \mathrm{H}), 1.10-1.35(\mathrm{~m}, 80 \mathrm{H}), 1.55(\mathrm{~m}, \mathrm{br}, 8 \mathrm{H}), 2.28(\mathrm{q}, 8$ H), 2.79(t, br, 4 H), 3.26(s, br, 4 H), 3.47(br, 4 H), 3.87(br, 8 H), 4.12(q, 2 H), 4.38(d, 2 $\mathrm{H}), 5.18(\mathrm{~m}, 2 \mathrm{H}), 7.73(\mathrm{br}, 2 \mathrm{H}, \mathrm{CONH})$. HRMS for $\left(\mathrm{C}_{72} \mathrm{H}_{136} \mathrm{O}_{18} \mathrm{~N}_{2} \mathrm{P}_{2} \mathrm{~S}_{2} \mathrm{Na}_{3}\right)$ MALDI $\left[\mathrm{M}^{2-}+3 \mathrm{Na}^{+}\right]^{+}$Calcd.: 1511.8393. Found: 1511.8352 .

Synthesis of $\mathbf{B}^{\prime} \mathbf{B}^{\prime}$. The procedure that was used for the preparation of $\mathbf{B}^{\prime} \mathbf{B}^{\prime}$ was similar to that used for the synthesis of $\mathbf{A}^{\prime} \mathbf{A}^{\prime}$. In this case, $0.1 \mathrm{mmol}(74.8 \mathrm{mg})$ 1,2-distearoyl-snglycero-3-phosphoethanolamine, $0.3 \mathrm{mmol}$ triethlyamine (TEA) and $0.05 \mathrm{mmol}(20.2$ $\mathrm{mg}$ ) of the activated ester (compound I) were used to give $47 \mathrm{mg}(54 \%)$ of B'B' having ${ }^{1} \mathrm{HNMR}\left(\mathrm{CDCl}_{3}, 500 \mathrm{MHz}\right): 0.86(\mathrm{t}, 12 \mathrm{H}), 1.10-1.35(\mathrm{~m}, 112 \mathrm{H}), 1.55(\mathrm{~m}, \mathrm{br}, 8 \mathrm{H}), 2.28(\mathrm{q}$, $8 \mathrm{H}), 2.79(\mathrm{t}, \mathrm{br}, 4 \mathrm{H}), 3.26(\mathrm{~s}, \mathrm{br}, 4 \mathrm{H}), 3.47(\mathrm{br}, 4 \mathrm{H}), 3.87(\mathrm{br}, 8 \mathrm{H}), 4.12(\mathrm{q}, 2 \mathrm{H}), 4.38(\mathrm{~d}, 2 \mathrm{H})$, 5.18(m, $2 \mathrm{H}), 7.73$ (br, $2 \mathrm{H}, \mathrm{CONH})$. HRMS for $\left(\mathrm{C}_{88} \mathrm{H}_{168} \mathrm{O}_{18} \mathrm{~N}_{2} \mathrm{P}_{2} \mathrm{~S}_{2} \mathrm{Na}_{3}\right)$ MALDI $\left[\mathrm{M}^{2-}\right.$ $\left.+3 \mathrm{Na}^{+}\right]^{+}$Calcd.: 1736.0897. Found: 1736.0904.

Synthesis of $\mathbf{A}^{\prime}$. The procedure that was used for the preparation of $\mathbf{A}^{\prime}$ was similar to that used for the synthesis of $\mathbf{A}^{\prime} \mathbf{A}^{\prime}$. In this case, $0.1 \mathrm{mmol}$ (64 mg) 1,2-dimyristoyl-snglycero-3-phosphoethanolamine, $0.3 \mathrm{mmol}$ triethlyamine (TEA) and $0.1 \mathrm{mmol}(22 \mathrm{mg})$ of activated ester (compound II) was used, affording $37 \mathrm{mg}(50 \%)$ of $\mathbf{A}^{\prime}$ having ${ }^{1} \mathrm{HNMR}\left(\mathrm{CDCl}_{3}, 500 \mathrm{MHz}\right): 0.86(\mathrm{t}, 6 \mathrm{H}), 1.10-1.35(\mathrm{~m}, 40 \mathrm{H}), 1.55(\mathrm{~m}, \mathrm{br}, 4 \mathrm{H}), 2.07(\mathrm{~s}, 3 \mathrm{H})$, 2.28(q, 4H), 2.49(t, 2H), 2.73(t, 2H), 3.43(br, 2H), 3.87(br, 4H), 4.12(q, 1H), 4.36(d, 1H), 5.18(m, 1H), 7.73 (br, $1 \mathrm{H}, \mathrm{CONH})$. HRMS for $\left(\mathrm{C}_{37} \mathrm{H}_{71} \mathrm{O}_{9} \mathrm{NPSNa}_{2}\right)$ MALDI [M$\left.+2 \mathrm{Na}^{+}\right]^{+}$Calcd.: 782.4377. Found: 782.4405.

Synthesis of $\mathbf{B}^{\prime}$. The procedure that was used for the preparation of $\mathbf{B}^{\prime}$ was similar to that used for the synthesis of $\mathbf{A}^{\prime} \mathbf{A}^{\prime}$. In this case, $0.1 \mathrm{mmol}(74.8 \mathrm{mg})$ of 1,2-distearoyl-snglycero-3-phosphoethanolamine, $0.3 \mathrm{mmol}$ triethlyamine (TEA) and $0.1 \mathrm{mmol}(21.7 \mathrm{mg}$ ) of the activated ester (compound II) was used, affording $45 \mathrm{mg}(53 \%)$ of $\mathbf{B}^{\prime}$ having ${ }^{1} \mathrm{HNMR}\left(\mathrm{CDCl}_{3}, 500 \mathrm{MHz}\right): 0.86(\mathrm{t}, 6 \mathrm{H}), 1.10-1.35(\mathrm{~m}, 60 \mathrm{H}), 1.55(\mathrm{~m}, \mathrm{br}, 4 \mathrm{H}), 2.07(\mathrm{~s}, 3 \mathrm{H})$, 2.28(q, 4H), 2.49(t, 2H), 2.73(t, 2H), 3.43(br, 2H), 3.87(br, 4H), 4.12(q, 1H), 4.36(d, 1H), 5.18(m, 1H), 7.73 (br, 1H, CONH). HRMS for $\left(\mathrm{C}_{45} \mathrm{H}_{87} \mathrm{O}_{9} \mathrm{NPSNa}_{2}\right)$ MALDI $\left[\mathrm{M}^{-}+2 \mathrm{Na}^{+}\right]^{+}$ Calcd.: 894.5629. Found: 894.5660. 
Nearest-Neighbor Recognition Measurements. In a typical liposome preparation, a test tube was charged with a chloroform solution that contained $0.15 \mu \mathrm{mol}$ of $\mathbf{A}^{\prime} \mathbf{A}^{\prime}, 0.15$ $\mu \mathrm{mol}$ of $\mathbf{A A A}$, and $0.30 \mu \mathrm{mol}$ of $\mathbf{B B}$. The chloroform was then evaporated by passing a stream of argon over the solution. The lipid mixture was then dissolved in $100 \mu \mathrm{L}$ of chloroform and diluted with $270 \mu \mathrm{L}$ of diisopropyl ether. Subsequent addition of $33 \mu \mathrm{L}$ of $3.3 \mathrm{mM}$ tris- $\mathrm{HCl}$ buffer $\left(3.3 \mathrm{mM}\right.$ tris- $\mathrm{HCl}, 50 \mathrm{mM} \mathrm{NaCl}, 0.67 \mathrm{mM} \mathrm{NaN}_{3}$ and $0.33 \mathrm{mM}$ EDTA, pH 7.4) produced an emulsion. After the emulsion was sonicated for 3 min, using a mild (bath-type) sonicator, the organic phase was removed by gentle evaporation at $60{ }^{\circ} \mathrm{C}$, resulting in a white gel at the bottom of the test tube. The gel was then collapsed by vigorous vortex mixing for $20-30 \mathrm{~min}$, and $2.0 \mathrm{~mL}$ of additional $10 \mathrm{mM}$ tris$\mathrm{HCl}$ buffer (10 mM tris- $\mathrm{HCl}, 150 \mathrm{mM} \mathrm{NaCl}, 2 \mathrm{mM} \mathrm{NaN}_{3}$ and $1 \mathrm{mM}$ EDTA, pH 7.4) was added dropwise with vortex mixing. The dispersion was then degassed with an aspirator for $5 \mathrm{~min}$, and the residual traces of organic solvent removed by dialysis (Spectra/Por Membrane, MWCO 6000-8000) under an argon atmosphere, using three $200 \mathrm{~mL}$ portions of degassed $10 \mathrm{mM}$ tris- $\mathrm{HCl}$ buffer, $\mathrm{pH} \mathrm{7.4)} \mathrm{over} \mathrm{the} \mathrm{course} \mathrm{of} 18 \mathrm{~h}$. Large unilamellar vesicles formed under these conditions were typically $1000 \mathrm{~nm}$ in diameter (dynamic light scattering).

Thiolate-disulfide interchange reactions were initiated, after the dispersions were equilibrated at $60^{\circ} \mathrm{C}$, by injecting $25.5 \mu \mathrm{L}$ of a tris-buffer solution of $37.65 \mathrm{mM}$ threodithiothreitol $(0.96 \mu \mathrm{mol})$ and $24 \mu \mathrm{L}$ of a tris-buffer solution, was $0.42 \mu \mathrm{M}$ in monensin (10.2 pmol), with brief vortex mixing, and finally increasing the $\mathrm{pH}$ to 8.5 via addition of ca. $10 \mu \mathrm{L}$ of $1.0 \mathrm{M} \mathrm{NaOH}$. All dispersions were maintained under an argon atmosphere throughout the course of the interchange reactions. Aliquots $(0.30 \mathrm{~mL})$ were withdrawn as a function of time and quenched with $80 \mu \mathrm{L}$ of $30 \mathrm{mM} \mathrm{HCl}$ (final $\mathrm{pH} 5.0$ ). After removal of water under reduced pressure, the residue was dissolved in $2 \mathrm{~mL}$ of chloroform and centrifuged for $20 \mathrm{~min}$. The chloroform layer was then removed under reduced pressure to yield a clear film, which was, subsequently, dissolved in $10 \mu \mathrm{L}$ of chloroform and $90 \mu \mathrm{L}$ of the mobile phase that was used for HPLC analysis. Product mixtures were analyzed by C18 reverse phase HPLC using a mobile phase that was composed of $10 \mathrm{mM}$ tetrabutylammonium acetate in denatured ethanol $/$ water $/$ hexane $=$ $82 / 11 / 7$ with flow rate of $0.9 \mathrm{~mL} / \mathrm{min}$. The column was maintained at $31{ }^{\circ} \mathrm{C}$ and the components were monitored at $205 \mathrm{~nm}$ by a Waters 996 -photodiode-array UV detector. 